\title{
NORTH CAROLINA
}

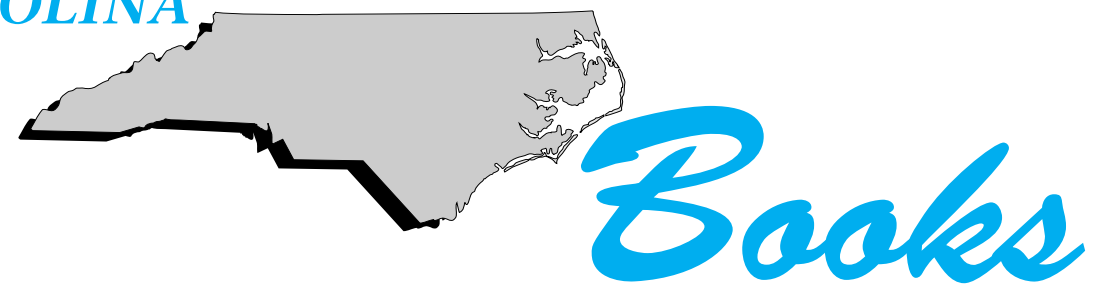

Dorothy Hodder, Compiler

e oastal North Carolina, and especially Wilmington and the Lower Cape Fear area, has been the location for many exciting events for more than four centuries. This book provides a comprehensive tool for discovering these sites.

In this easy-to-use guide, author Jack E. Fryar, a native of Wilmington, offers an illustrated tour of the many historical tourism stops in the southeastern part of the state. The list of entries is color-coded by location and includes a wide

Jack E. Fryar, Jr. range of sites, including the gardens, cemeteries, museums, and even the North Carolina Room at the New Hanover County Public Library.

Arranged by location, each page-length entry

A History Lover's Guide to Wilmington and the Lower Cape Fear: Southeastern North Carolina's Best Historical Tourism Attractions, How to Get There, When They're Open and What Makes Them Worth Your Time.

Wilmington: Dram Tree Books, 2003. 134 pp. Paper, \$17.95. ISBN 0-9723240-1-1. provides such useful information as address, phone number, admission price, and hours of operation as well as a simple map to the site. In addition, Web addresses are given when available. For each entry the description is complemented by pictures, both recent and from past days, and interesting stories detailing the reasons the sites are important in our history.

Fryar has also included a collection of very brief entries covering the northern coast of North Carolina. Although the entries in this section are short, they include addresses and contact information with a brief description. Other useful data include a list of regional tourism offices with phone numbers and Web sites and a useful calendar of events for the area.

This guidebook provides a useful tour of the area's many historical locations. Even though sometimes difficult to read because of the fullpage single paragraph entries and editorial errors, this book is suitable for public libraries and academic libraries with North Carolina collections because of its unique qualities and comprehensive coverage.

Jack Fryar is the editor of The Coastal Chronicles, Volume I (Dram Tree Books, ISBN 0-9723240-0-3) a collection of true stories about the Cape Fear and North Carolina Coast, and the publisher of a monthly e-magazine Coastal Chronicles On-Line. 
Orrin H. Pilkey, William J. Neal, and Tracy Monegan Rice.

\section{How to Read a North Carolina Beach: Bubble Holes, Barking Sands, and Rippled Runnels.}

Chapel Hill: University of North Carolina Press, 2004. 176 pp. Paper, \$12.95. ISBN 0-8078-5510-3. f you live on or visit any of North Carolina's barrier islands, there is a good chance that you have heard of Orrin Pilkey. He is James B. Duke Professor Emeritus of Geology at Duke University and his areas of experPilkey is the author of over 150 technical publications and has authored or co-authored 17 books on the topics of coastal geology and the ecology of shorelines. Tracy Monegan Rice is a coastal geologist working for the federal government and William J. Neal is professor of geology at Grand Valley State University in Allendale, Michigan. Pilkey and Neal are editors of the Living with the Shore book series.

In their collaborative effort, How to Read a North Carolina Beach, these three coastal experts take their readers on a very unusual beach excursion. Along the way, you learn what makes sea foam and find an explanation for those tiny sand volcanoes that pop up along the waterline. The book includes an interpretation of large-scale beach processes such as the composition and interaction of wind, waves, and sand; deciphers the smaller actions of drift lines, black sands, and bubble holes; and helps to unravel the mysteries of barking sands, blisters, rings, and rippled runnels. In addition, the authors provide a study of beach life forms ranging from meiofauna (microscopic organisms living in the cavities between grains of sand) and macrofauna (crabs, clams, turtles, birds, etc.).

The final chapter is devoted to a discussion of the future of North Carolina's beaches, including the man-made threats to their survival and an analysis of various strategies for conservation. For those familiar with Pilkey's research, it will come as little surprise that this last chapter is biased. The authors argue against any interference with the natural ebb and flow of barrier islands. Their position is made very clear: if we continue with the over development of our shorelines and insist on utilizing beach nourishment projects, sand bags and sea walls for dealing with beach erosion, there will be no beaches left behind for future generations. While some may view this as "alarmist" rhetoric, there can be no denying that Pilkey and his co-authors base their arguments on well-established and scholarly inquiry. These arguments give readers much to contemplate and consider.

How to Read a North Carolina Beach is a comprehensive field guide to the beaches of our state. It is entertaining as well as thought-provoking and educational. An extensive index, a glossary of beach terminology, and a list of suggested readings are sound enhancements. Additionally, there are 8 color and 79 black-and-white photographs, 10 illustrations, 4 tables, and 2 maps to aid in understanding the material presented. How to Read a North Carolina Beach is suitable for public and academic libraries and will appeal to both naturalists and vacationers.

Cape Fear Community College 
$\eta$ is no coincidence that Robert Irwin did not get his "true start as a painter" until Athens Train Station, for his is a journey readers will find most intriguing. Published by Dancingfish Press, this book contains over 150 full-color illustrations of Irwin's work spanning almost 40 years of his life (1964-2000).

Irwin, a graduate of the North Carolina University School of Design, Shaw University and former student of the University of Georgia, shares personal and professional experiences that have shaped him into the artist he is now.

Irwin, Robert. Along with autobiographical text, Irwin takes readers

\section{Robert F. Irwin: 40 Years.}

Valle Crucis: Dancingfish Press, 2004. $180 \mathrm{pp}$. illus. index. $\$ 85.00$. ISBN 1-879802-406. through the timeline of his life, sharing his experiences as photographer, art instructor, art museum designer and founder/president of his own furniture company. On this transformative journey, readers see Irwin's multifaceted ability to work with various mediums such as watercolor, photography, sculpture, and acrylic.

In his earlier works, Irwin takes readers back in time with dream-like images of the South, such as Athens Georgia Interior Store, Oconee River, and House in East Wake County. In the second half of the book, Irwin really emerges as an artist with his vibrant yet tranquil scenes from the Eastern Seaboard. His unique use of color and light is evident in Banks Channel VI and in Cape Lookout, all invoking the same feelings of quiet reflection. Towards the end, Irwin describes his method or process along with subject, which many readers will find informative. If Irwin's goal was to pay homage to all of those who have influenced him, e.g. George Bireline, Joe Cox, and Wiley Sanderson (just to name a few), he has certainly done so, and has proven himself an established artist at that!

The book includes an index as well as a chronology. Recommended for academic and large public libraries.

— Justine Roach

New Hanover County Public Library

\section{Don't Be Shy!}

If you would like to review a North Carolina book

for North Caralina Baoks

contact Dorothy Hodder at 910-798-6323

or e-mail at dhodder@nhcgov.com 